\title{
A new species of the genus Stagetus Wollaston, 1861 (Coleoptera: Ptinidae: Dorcatominae) from Eocene Baltic amber
}

\author{
Jiří Háva \& Petr ZaHradník
}

Forestry and Game Management Research Institute, Strnady 136, CZ-156 00 Praha 5-Zbraslav, Czech Republic e-mail: jh.dermestidae@volny.cz e-mail: zahradnik@vulhm.cz

Háva, J. \& Zahradník, P.: A new species of the genus Stagetus Wollaston, 1861 (Coleoptera: Prinidae: Dorcatominae) from Eocene Baltic amber.

Abstract: A new species, Stagetus arturi sp. nov., from Eocene Baltic amber is described, illustrated and compared with a similar species, S. makarovi Zahradník, 1997.

Keywords: Taxonomy, new species, Coleoptera, Ptinidae, Dorcatominae, Stagetus, Eocene Baltic amber, Poland.

\section{Introduction}

The family Ptinidae (Coleoptera) from Baltic amber was recently studied by the following authors: Alekseev 2012, 2013, 2014, AleKseEv \& Bukejs 2019a,b, AleKsEev et al. 2019, Bukejs \& Alekseev 2015, Bukejs et al. 2017, 2018, Háva \& ZAHradník 2019a, b, 2020a,b,c, ZAHRADNíK \& HÁvA 2014, 2017, 2019.

A new species described here from Eocene Baltic amber collected in Poland belongs to the genus Stagetus Wollaston, 1861. The genus Stagetus Wollaston, 1861 currently contains about 70 species worldwide, 55 species and subspecies are known from Palaearctic Region (ZAHRADNíK 2003, 2012, 2015, ViŇOLAS 2012, 2013, 2016a,b, 2017, ViŇolas \& Masó 2006, Toskina 2012, 2015). The species described here is the first known species of Stagetus from Baltic amber.

\section{Material and methods}

The habitus photograph was taken by a digital camera using Canon EOS 4000D on stereobinocular microscope Nikon SMZ800 + SMZ1500 + PLAN APO lens. 
The type material is deposited in the following collection:

JHAC - Private Entomological Laboratory and Collection, Jiří Háva, Únětice u Prahy, Prague west, Czech Republic.

Holotype specimen of the new species described here is provided with a red, printed label showing the following text: "Holotype Stagetus arturi sp. nov. J. Háva \& $\mathrm{P}$. Zahradník det. 2020".

\section{Results}

\section{Subfamily Dorcatominae}

Stagetus arturi sp. nov. (Figs. 1-2)

Type material: Holotype (unsexed): Amber inclusion No. 5946, Poland, Gdansk city area, (JHAC).

The complete beetle is included in a transparent amber piece, with dimensions of $30 \times 23 \mathrm{~mm}$. Syninclusions consist of numerous minute organic particles and one very small specimen of Acari (Arachnida).

Description of holotype: Body oval (Fig. 1), transversally and longitudinally convex, body length $1.3 \mathrm{~mm}$, the greatest width $0.5 \mathrm{~mm}$ (in amber situation). Pronotum, head, elytra, abdomen and legs brown, antennae not visible.

Head hypognathous, almost flattened, finely punctured, punctures almost touched. Eyes large, rounded, slightly convex, glabrous. Antennae and palpi not visible.

Pronotum about as long as wide, trapeziform (Fig. 1), finely punctured, shiny, with very short yellow setation. The greatest width very shortly before base. Posterior angles obtusely rounded (in dorsal view); anterior part of pronotum slightly raised.

Scutellum triangular, very small.

Elytra shortly oval, shining, with distinct shoulders, with very short yellow setation. Each elytron with eleven striae consisting of punctures; punctures are large, defined discally and near apex of elytron, eleventh elytral stria ends at the second half of elytron. Prosternum and metasternum with small individual punctures laterally.

Legs robust and short, brown, tarsi short light brown.

All abdominal visible ventrites of the same length, with small punctures medially.

Differential diagnosis: The new fossil species differs from other known recent Palaearctic species keyed by ToskinA (2015) by the small body form, brownish cuticle and elytral striation. The new species belongs to the "byrrhoides species group" and is very similar to S. makarovi Zahradnik, 1997, but differs from it by the following characters.

S. makarovi Zahradnik, 1997: body length $1.7 \mathrm{~mm}$, body light brown; setation white; setation on elytra double - very short, dense and recumbent, and long, sparse and erect; eleventh elytral stria ends at the first third of the length of elytron.

S. michalskii sp. nov.: body length $1.3 \mathrm{~mm}$; body light brown; setation on elytra yellow, very short, not double; eleventh elytral stria ends at the second half of elytron.

Etymology: Patronymic, dedicated to amber specialist Artur Michalski (Wroclaw, Poland). 

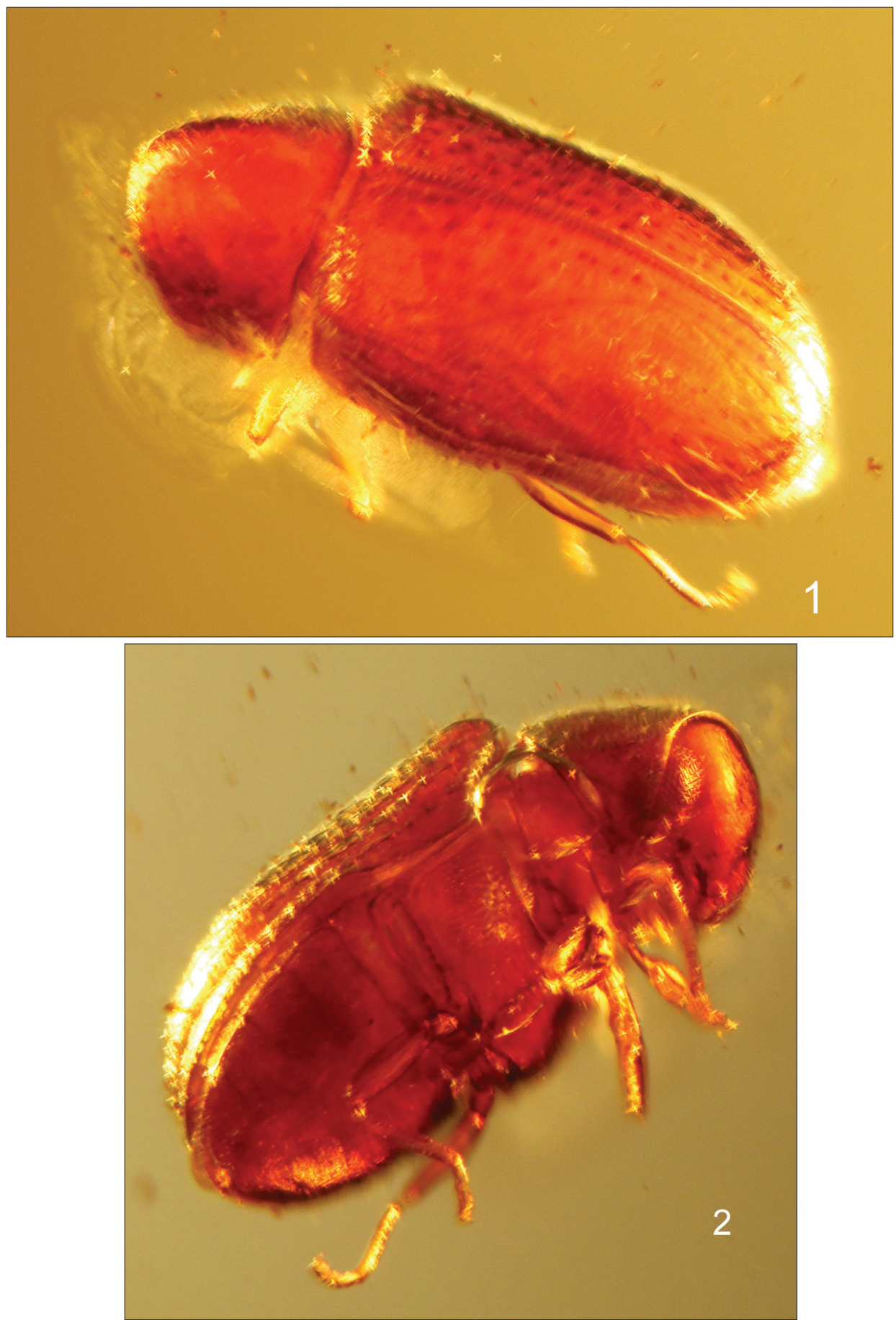

Figs. 1-2: Stagetus arturi sp. nov.: 1- habitus in dorsal view; 2- habitus in ventral view (photo by A. Michalski) 


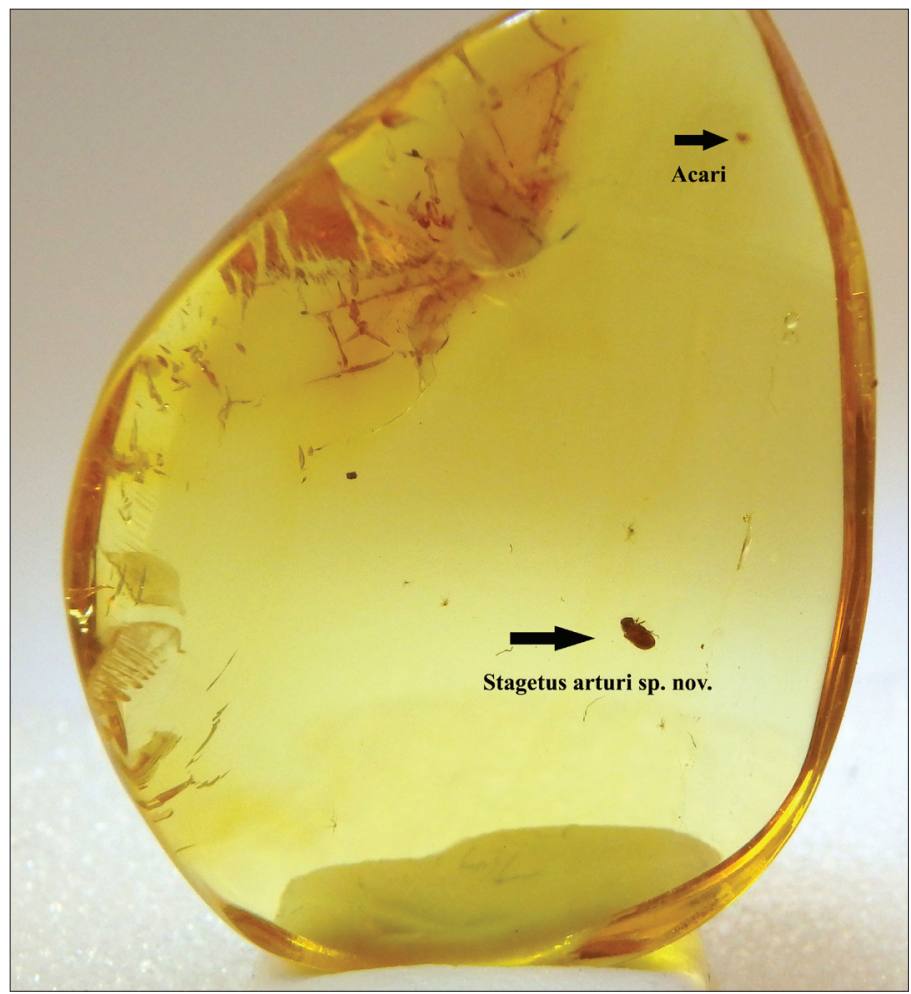

Fig. 3: Amber inclusion with holotype Stagetus arturi sp. nov. (photo by A. Michalski)

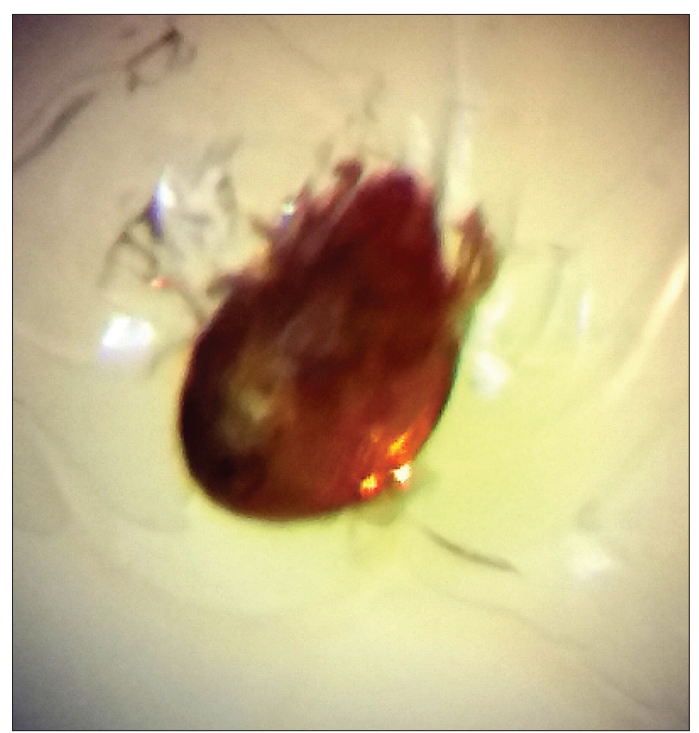

Fig. 4: Syninclusion specimen of Acari (Arachnida) (photo by J. Háva) 


\section{Acknowledgements}

We are indebted to Artur Michalski (Poland) for providing us with the interesting material and to Miloslav Rakovič (Czech Republic) for linguistic correction. The paper was supported by the Ministry of Agriculture of the Czech Republic, institutional support MZE-RO0118.

\section{References}

Alekseev, V. I. 2012: Sucinoptinus bukejsi sp. nov. (Coleoptera: Ptinidae: Ptinini), the second species of the Tertiary genus from the Baltic amber. - Baltic Journal of Coleopterology 12: 145-148.

Alekseev, V. I. 2013: The beetles (Insecta: Coleoptera) of Baltic amber: the checklist of described species and preliminary analysis of biodiversity. - Zoology and Ecology 23: 5-12. https://doi.org/10.1080/21658005.2 013.769717

Alekseev, V. I. 2014: New fossil species of Ptinidae (Insecta: Coleoptera) in Baltic Amber (Tertiary, Eocene). - Zoology and Ecology 24(3):239-255. https://doi.org/10.1080/21658005.2014.909154

Alekseev, V. I. \& Bukess, A. 2019a: Two new species of Xyletinus Latreille (Ptinidae: Xyletininae) in Eocene Baltic amber. - Zootaxa 4668(4): 525-534. https://doi.org/10.11646/zootaxa.4668.4.5

Alekseev, V. I. \& Bukess, A. 2019b: Xyletinus (s. str.) thienemanni sp. nov., a new species of Xyletininae (Coleoptera: Ptinidae) from Eocene baltic amber. - Acta Biologica Universitatis Daugavpiliensis 19(1): 31-35.

Alekseev, V. I., Bukejs, A. \& Bellés, X. 2019: Dignoptinus, a new genus for fossil Dignomus regiomontanus Alekseev from Eocene Baltic amber, and new status for Bruchoptinus Reitter and Pseudoptinus Reitter (Coleoptera: Ptinidae). - Fossil Record 22: 65-72. https://doi.org/10.5194/fr-22-65-2019

Bukejs, A. \& Alekseev, V. I. 2015: A second Eocene species of death-watch beetle belonging to the genus Microbregma Seidlitz (Coleoptera: Bostrichoidea) with a check list of fossil Ptinidae. - Zootaxa 3947(4): 553-562. https://doi.org/10.11646/zootaxa.3947.4.6

Bukejs, A., Alekseev, V. I., Cooper, D. M. L., King, G. A. \& McKellar, R. C. 2017: Contributions to the palaeofauna of Ptinidae (Coleoptera) known from Baltic Amber. - Zootaxa 4344(1): 181-188. https://doi.org/10.11646/zootaxa.4344.1.12

Bukejs, A., Bellés, X. \& Alekseev, V. I. 2018: A new species of Dignomus Wollaston (Coleoptera: Ptinidae) from Eocene Baltic amber. - Zootaxa 4486(2): 195-200. https://doi.org/10.11646/zootaxa.4486.2.9

Bukejs, A., Háva J. \& Alekseev, V. I. 2018: New fossil species of Trichodesma LeConte, 1861 (Coleoptera:

Ptinidae) from Eocene Baltic amber collected in the Kaliningrad region, Russia. - Paleontologia Electronica 21(2): 1-7. https://doi.org/10.26879/848

Háva, J. \& Zahradník, P. 2019a: A new Falsogastrallus Pic, 1914 species (Coleoptera: Ptinidae) from Eocene Baltic amber. - Studies and Reports, Taxonomical Series 15(1): 59-62.

Háva, J. \& Zahradník, P. 2019b: Two new species of the genus Xyletinus Latreille, 1809 in Eocene Baltic Amber (Coleoptera: Bostrichoidea: Ptinidae). - Folia Heyrovskyana, Series A 27(2): 13-16.

Háva, J. \& Zahradník, P. 2020a: Three new species of Ptininae (Coleoptera: Bostrichoidea: Ptinidae) from Eocene Baltic amber. - Studies and Reports, Taxonomical Series 16(1): 85-91.

Háva, J. \& Zahradník, P. 2020b: Contribution to the Ptinidae (Coleoptera) from Eocene Baltic amber, with descriptions of two new species. - Folia Heyrovskyana, Series A 28(1): 15-19.

Háva, J. \& Zahradník, P. 2020c: Two new species of Ptinidae (Coleoptera) from Eocene Baltic amber. Natura Somogyiensis 35: 5-10. https://doi.org/10.24394/NatSom.2020.35.5

ToskinA, I. N. 2012: Some new palaearctic species of the genus Stagetus Wollaston, 1861 (Coleoptera: Ptinidae: Dorcatominae). - Bulletin of the Moscow Society of Naturalists., Ser. Biol. 117(2): 16-28.

Toskina, I. N. 2015: Key to Palaearctic species of the genus Stagetus (Coleoptera, Ptninidae, Dorcatominae). - Vestnik Zoologii 49(1): 13-34. https://doi.org/10.1515/vzoo-2015-0002

VIŇOLAS,A. 2012: Stagetus cobosi n. sp. de Dorcatominae d'Almeria, península Ibèrica (Coleoptera: Ptinidae). - Orsis 26: 187-192.

VIÑolas, A. 2013: Els Dorcatominae de la península Ibèrica i illes Balears. 3a nota. El gènere Stagetus Wollaston, 1861, amb la descripció de S. confusus n. sp. (Coleoptera: Ptinidae). - Orsis 27: 95-121. 
ViÑolas, A. 2016a: Un nuevo Stagetus Wollaston, 1861 de Castellón, Península Ibérica (Coleoptera: Ptinidae: Dorcatominae). - Arquivos Entomolóxicos 15: 57-64.

ViÑolaS, A. 2016b: Una nueva especie del género Stagetus Wollaston, 1861 de Teruel, Península Ibérica (Coleoptera: Ptinidae: Dorcatominae). - Arquivos Entomolóxicos 16: 151-158.

ViŇOlas, A. 2017: Nueva aportación al conocimiento de los Ptinidae (Coleoptera) de la Península Ibérica e Islas Canarias, con la descripción de un nuevo Stagetus Wollaston, 1861 de Navarra. - Arquivos Entomolóxicos 18: 137-148.

ViŇolas, A. \& Masó, G. 2006: Revisión del género Stagetus Wollaston, 1861, en el África continental. Butlletí de la Institució d'História Natural 74: 37-80.

ZAhradní, P. 2007: Genus Stagetus pp. 346-347. In: LöBl, I \& SMETANA, A. (eds.): Catalogue of Palaearctic Coleoptera. Volume 4: Elateroidea - Derodontoidea - Bostrichoidea - Lymexyloidea - Cleroidea Cucujoidea. Stenstrupp: Apollo Books, 935 pp.

Zahradník, P. 2012: Ptinidae of China I. - Subfamily Dorcatominae (Coleoptera: Bostrichoidea: Ptinidae). Studies and Reports, Taxonomical Series 8(1-2): 325-334.

ZAhradník, P. 2015: A review of Ptinidae (Coleoptera: Bostrichoidea) of Socotra Island. - Studies and Reports, Taxonomical Series 11(1): 197-220.

Zahradník, P. \& Háva, J. 2014: New Ptinidae (Coleoptera: Bostrichoidea) from Baltic amber with a list of known fossil species. - Studies and Reports, Taxonomical Series 10(2): 629-646.

Zahradník, P. \& Háva, J. 2017: Three new species of Trichodesma LeConte, 1861 from Baltic Amber (Coleoptera: Ptinidae: Anobiinae). - Folia Heyrovskyana, Series A 25(1): 89-92.

ZAhradNík, P. \& Háva, J. 2019: Gastrallus michalskii sp. nov., a new species of tribe Gastrallini (Coleoptera: Ptinidae) from Eocene Baltic amber. - Acta Biologica Universitatis Daugavpiliensis 19(2): 231-233. 